https://helda.helsinki.fi

Mercury concentrations in an aquatic ecosystem during twenty years following abatement the pollution source

\title{
Lodenius, $\mathrm{M}$.
}

Kluwer Academic Publishers

1991

Lodenius, M. 1991. Mercury concentrations in an aquatic ecosystem during twenty years following abatement the pollution source. Water, Air and Soil Pollution 56: 323-332.

http://hdl.handle.net/1975/190

Downloaded from Helda, University of Helsinki institutional repository.

This is an electronic reprint of the original article.

This reprint may differ from the original in pagination and typographic detail.

Please cite the original version. 


\title{
MERCURY CONCENTRATIONS IN AN AQUATIC ECOSYSTEM DURING TWENTY YEARS FOLLOWING ABATEMENT THE POLLUTION SOURCE
}

\author{
Martin Lodenius \\ Department of Environmental Conservation \\ University of Helsinki \\ SF-00710 Helsinki, Finland
}

\begin{abstract}
Phenyl $\mathrm{Hg}$ was widely used as a slimicide in Finnish pulp industry until the end of 1967. The use of $\mathrm{Hg}$ caused a significant increase of Hg levels in fish in several areas. High concentrations were measured in Lake Kirkkojärvi in Hämeenkyrö, SW Finland. Vast amounts of $\mathrm{Hg}$ are still present in the lake sediments. Since 1968 uncontaminated fibres have partly covered the contaminated layers. Since $1971 \mathrm{Hg}$ has been monitored in fish, sediments and acquatic plants in the water course downstream from the pulp and paper factory. The $\mathrm{Hg}$ concentration of a $1-\mathrm{kg}$ pike (Esox lucius) has decreased from $1.5 \mu \mathrm{g} \mathrm{g} \mathrm{g}^{-1}$ in the years $1971-74$ to $0.8 \mu \mathrm{g} \mathrm{g}^{-1}$ in 1990 .
\end{abstract}

\section{INTRODUCTION}

Phenyl $\mathrm{Hg}$ was widely used as a slimicide in Finnish pulp industry until the end of 1967. The use of $\mathrm{Hg}$ caused a significantly increased level of $\mathrm{Hg}$ in fish in several areas. The highest concentration ever measured in Finland $\left(6.9 \mu \mathrm{gg}^{-1}\right)$ was recorded in 1975 from Lake Kirkkojärvi in Hämeenkyrö, SW Finland. During the first years after the ban of phenyl $\mathrm{Hg}$ no fish samples were analyzed for $\mathrm{Hg}$. Starting in 1971 the $\mathrm{Hg}$ pollution has been monitored for $20 \mathrm{yr}$ in the water course downstream from the paper and cardboard factory.

\section{MATERIAL AND METHODS}

2.1 Study area

The Hämeenkyrö water course is situated in SW Finland (Figure 1). The paper and cardboard factory is situated downstream from the unpolluted Lake

Water, Air, and Soil Pollution 56: 323-332, 1991.

(0) 1991 Klwwer Acalemic: Publishers. Printed in the Netherlands. 
Kyrösjärvi on the shore of River Pappilanjoki. The effluents of the factory contained $\mathrm{O}_{2}$ consuming compounds (fibres) nutrients and phenyl $\mathrm{Hg}$. The exact amount of $\mathrm{Hg}$ released is unknown. Since 1968 uncontaminated fibres have partly covered the $\mathrm{Hg}$ contaminated layers.

The mean flow of River Pappilanjoki is $24 \mathrm{~m}^{3} \mathrm{~s}^{-1}$ and most of the fibres discharged from the factory are deposited in the sediments of Lake Kirkkojärvi. This lake is eutrophic with periodically occurring $\mathrm{O}_{2}$ depletion in the hypolimnion. The color values are high: 80 to $100 \mathrm{mg} \mathrm{Pt} \mathrm{L}^{-1}$.

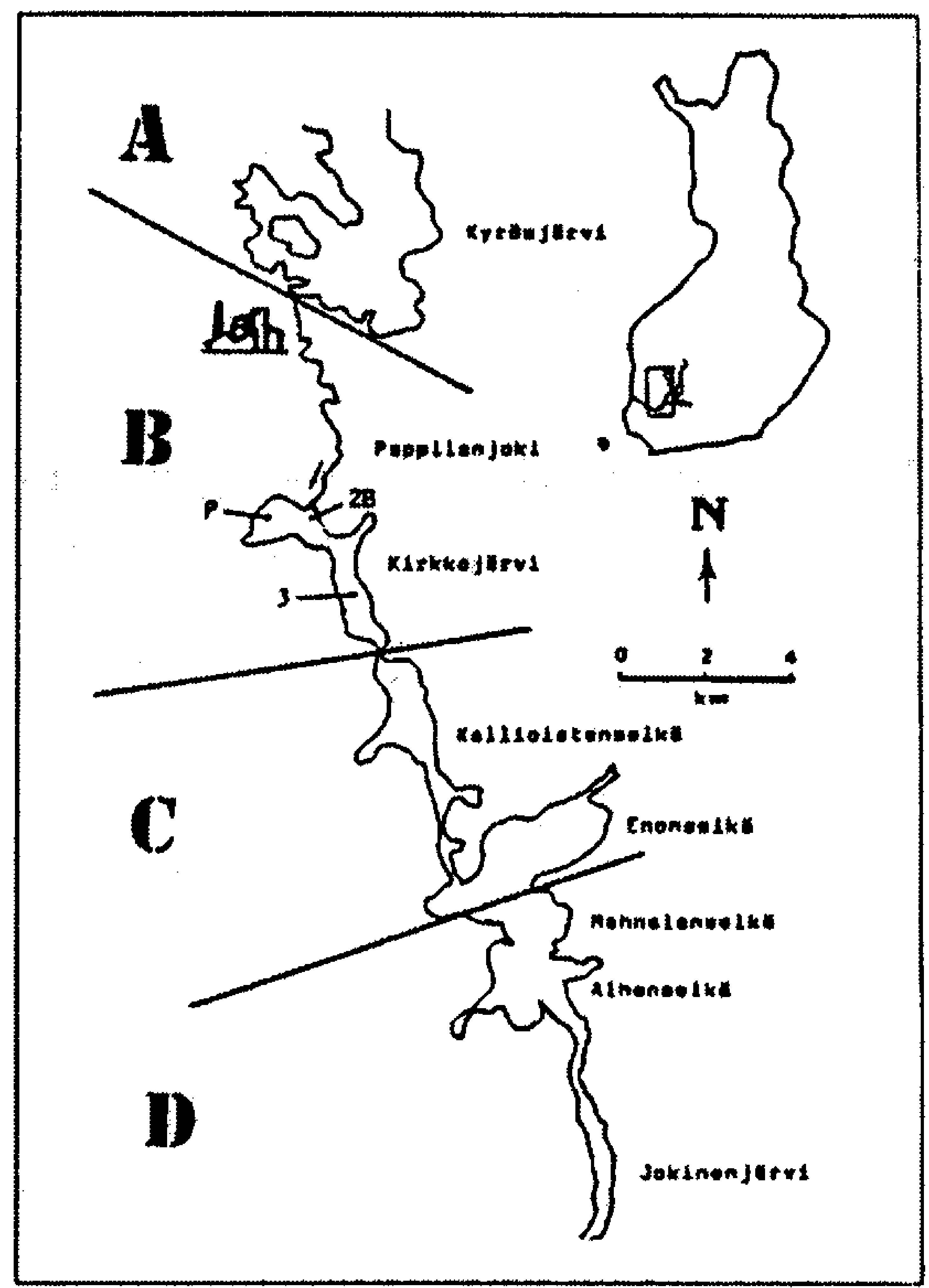

Fig. 1. The study area divided into four subareas $(A, B, C, D)$ and the sampling sites for sediments and aquatic plants $(2 \mathrm{~B}, \mathrm{P}, 3)$.

2.2 Samples of sediments, aquatic plants and fish

Sediment samples have been collected regularly since 1972 (unpublished reports by the Kokemäenjoki River Water Protection Association). A sediment profile was collected from the deepest site (site 3) of Lake Kirkkojärvi in August 1988 using a sediment corer $(\phi 6.9 \mathrm{~cm})$. Two additional samples were collected from the same lake from shallow water (sites $2 \mathrm{~B}$ and $\mathrm{P}$ ). The sediment cores were sliced into 1 to $4 \mathrm{~cm}$ thick samples.

Samples of aquatic plants were collected in 1976 (Suominen $e t$ al., 1977), in 1978 (Lodenius, 1980) and in 1988 (from three sites). The plants samples were dried $\left(+40^{\circ} \mathrm{C}\right)$ and homogenized.

The fish material consists of literature data (Nuorteva et al., 1975; Anon., 1976; Mankki, 1982, 1989; Mankki and Näsi, 1985) and fish sent to our laboratory for $\mathrm{Hg}$ analyses. Part of the data have been published earlier (Nuorteva et al., 1989; Lodenius, 1988). Muscle $\mathrm{Hg}$ data are available for 294 specimens of Northern Pike (Esox lucius). Since 1979 samples of liver $(\mathrm{N}=129)$, kidney $(\mathrm{N}=123)$ and gonads 
$(\mathrm{N}=72)$ have been collected in addition to muscle samples. The fish samples were stored frozen before analysis.

\subsection{Mercury analyses}

The samples were digested in concentrated $\mathrm{H}_{2} \mathrm{SO}_{4}$ and $\mathrm{HNO}_{3}$ acid in an aluminium hot block $\left(+85^{\circ} \mathrm{C}\right)$. The concentrations of $\mathrm{Hg}$ were measured using cold vapor atomic absorption spectrometry (Coleman MAS-50).

\section{RESULTS}

3.1 Sediments

The Hg concentrations of the surficial sediment of Lake Kirkkojärvi have decreased steadily since the beginning of the 1970's. From $2.1 \mu \mathrm{g} \mathrm{g}^{-1}$ (dw) in 1972 ,
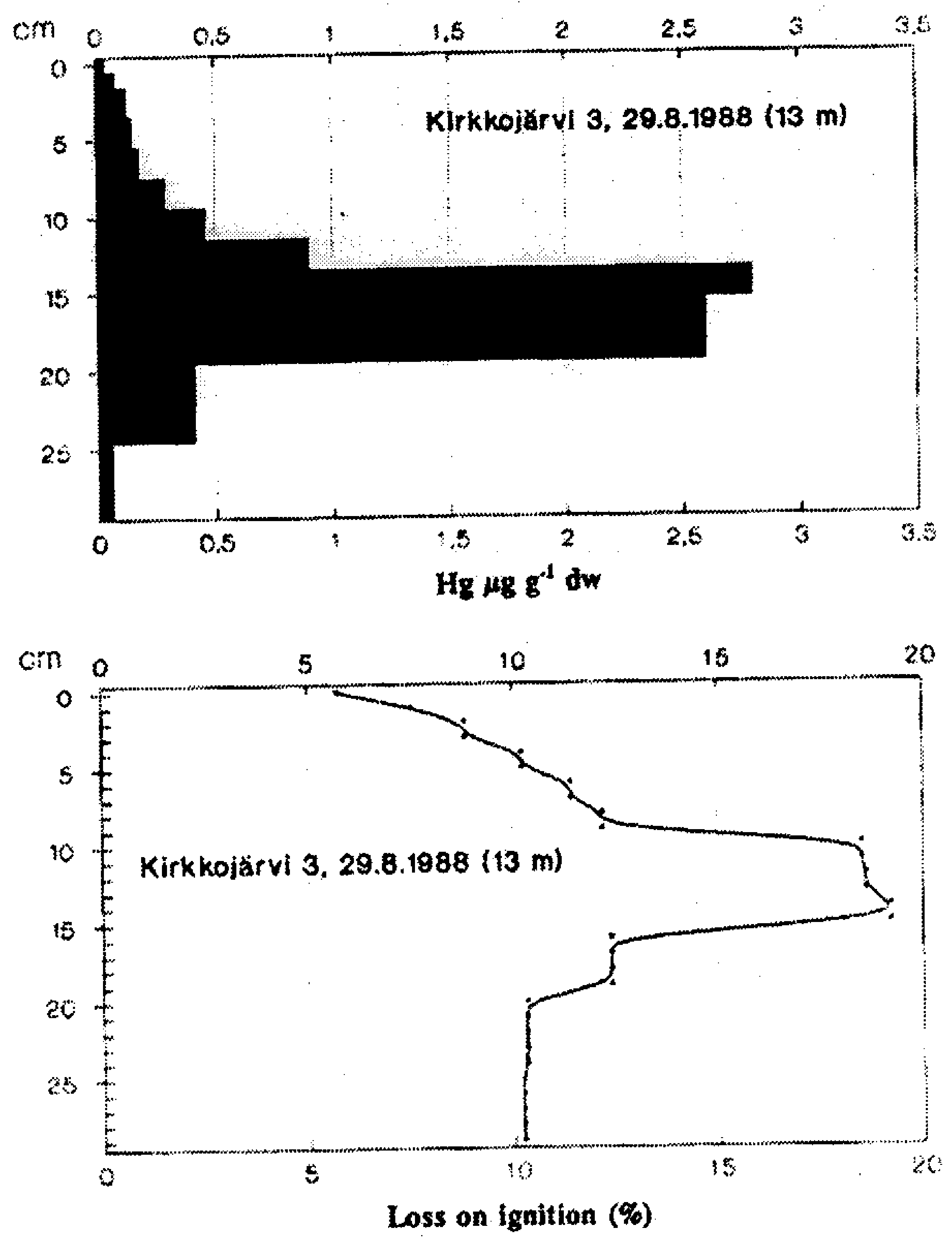

Fig. 2. $\mathrm{Hg}$ concentrations ( $\mu \mathrm{g} \mathrm{g}-1 \mathrm{dry} w \mathrm{wt}$ ) and loss on ignition (\%) of sediments from Lake Kirkkojärvi (site 3, depth $13 \mathrm{~m}$ ) collected in August 1988. 
it decreased to $0.4 \mu \mathrm{g} \mathrm{g}^{-1}$ in 1981 (Kokemäki River Water Protection Association, unpublished results).

The sediment profile from the deepest site $(13 \mathrm{~m})$ of Lake Kirkkojärvi collected in 1988 confirm that the old, highly polluted sediment layers are covered by more recent, unpolluted $\left(0.02 \mu \mathrm{g} \mathrm{g}^{-1}\right)$ sediments (Figure 2$)$. Near the mouth of River Pappilanjoki, where the current is strong, the surficial sediment contained $0.04 \mu \mathrm{g} \mathrm{g}^{-1}$ while the surficial $\mathrm{Hg}$ concentration was somewhat higher $\left(0.12 \mu \mathrm{g} \mathrm{g}^{-1}\right)$ in the semi-enclosed bay at site P (Figures 3 and 4).
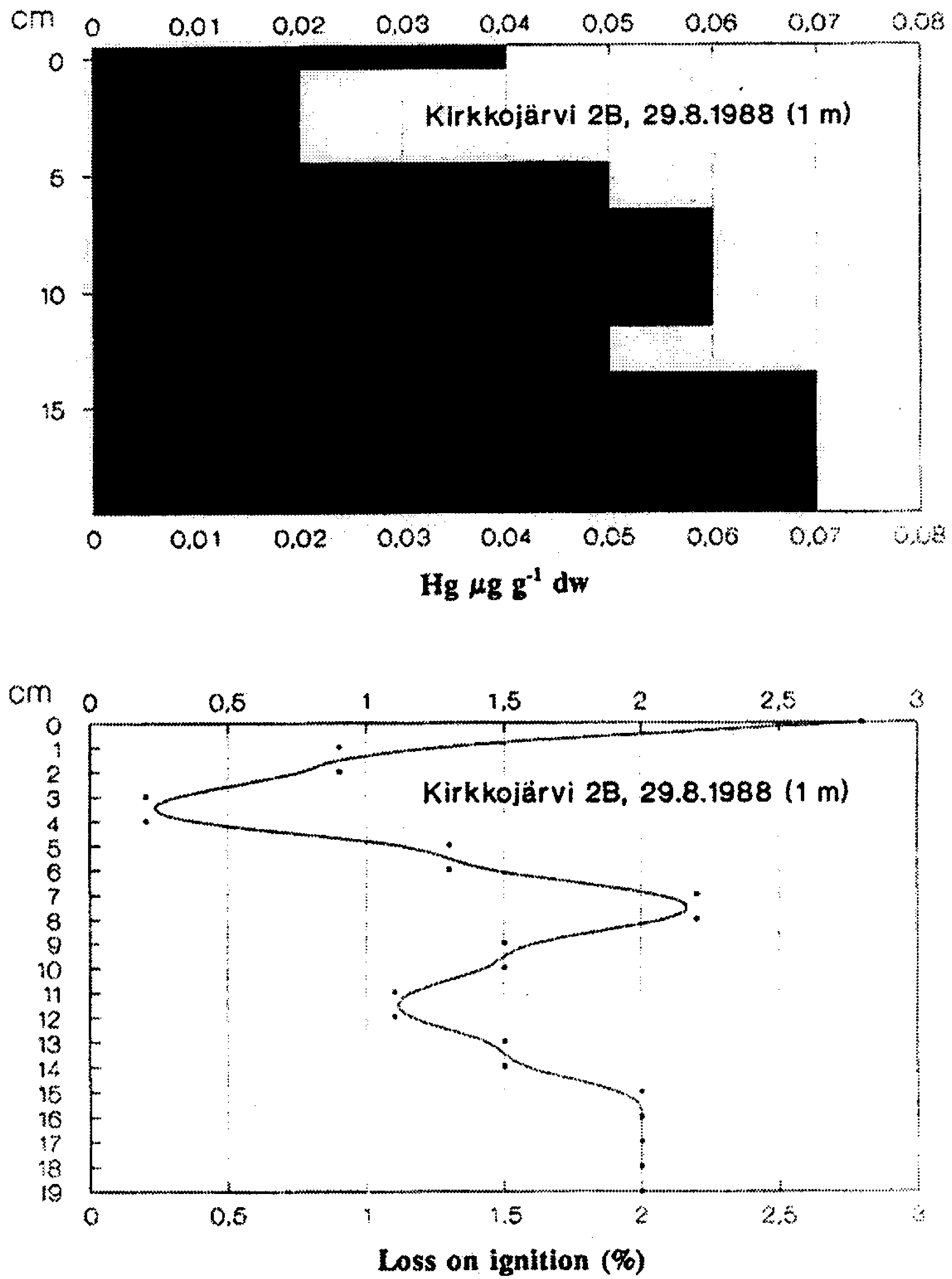

Fig. 3. $\mathrm{Hg}$ concentrations ( $\left.\mu \mathrm{g} \mathrm{g}^{-1} \mathrm{dry} w \mathrm{wt}\right)$ and loss on ignition (\%) of sediments from Lake Kirkkojärvi (site 2B, depth $1 \mathrm{~m}$ ) collected in August 1988. 

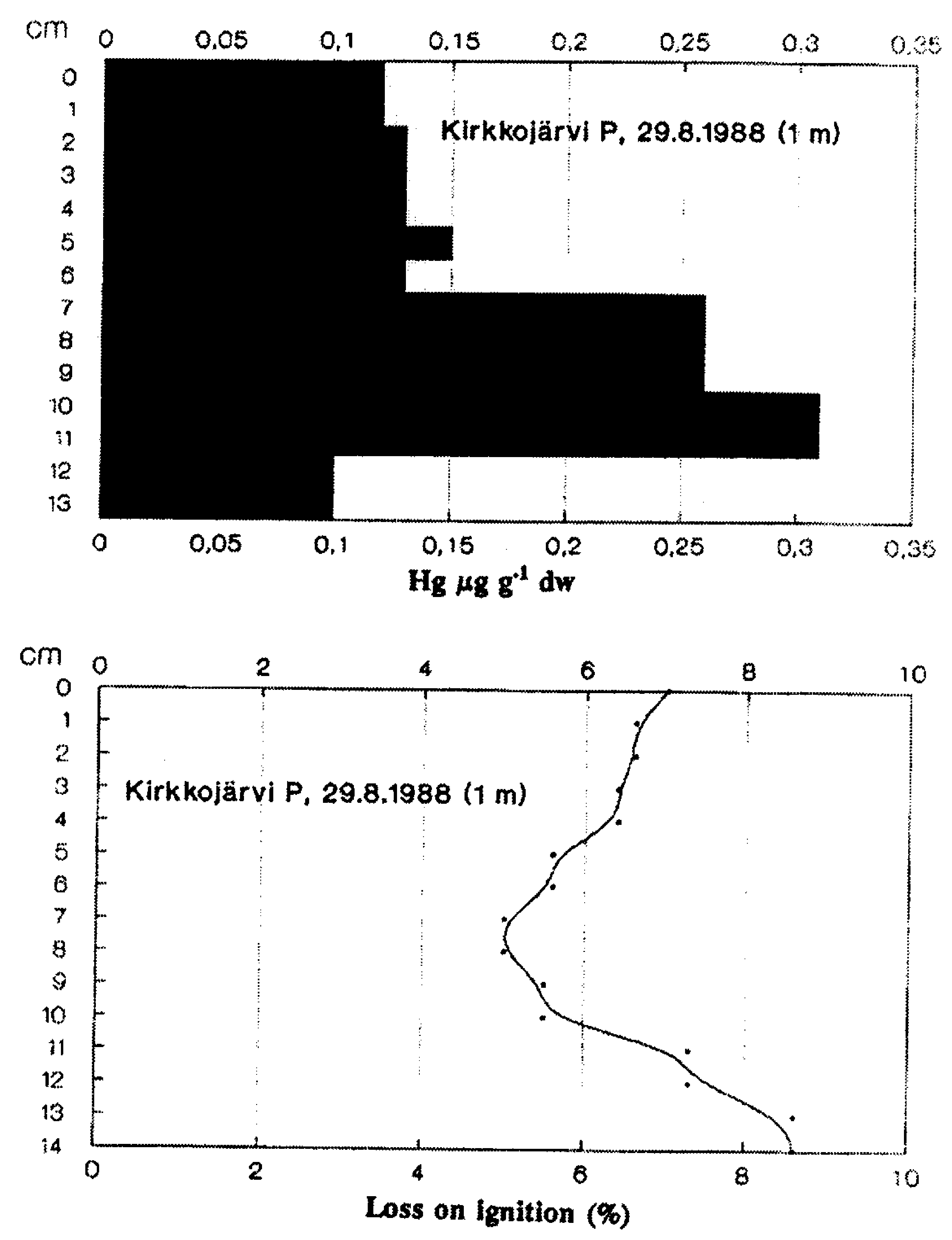

Fig. 4. Hg concentrations ( $\mu \mathrm{g} g-1 \mathrm{dry} w t)$ and loss on ignition (\%) of sediments from Lake Kirkkojärvi (site P, depth $1 \mathrm{~m}$ ) collected in August 1988.

\subsection{Aquatic plants}

Aquatic plants collected in the 1970's (Table I) were slightly elevated in $\mathrm{Hg}$ content as compared to unpolluted sites. In 1988 the $\mathrm{Hg}$ level was at the background level ( $c f$. Lodenius, 1980). No differences were detected between the three sampling sites. 
Table I. Hg concentrations ( $\mu \mathrm{g} g-1$ dry wt) of aquatic plants in Kirkkojärvi, Hämeenkyrö. The samples are collected in 1976 (Suominen et al., 1977, 1978; Lodenius, 1980) and from three different sites in 1988.

\begin{tabular}{|c|c|c|c|c|c|}
\hline \multirow[b]{3}{*}{ Sparganium friesii } & \multirow{3}{*}{$\frac{1976}{0.07}$} & \multirow[t]{3}{*}{1978} & \multicolumn{3}{|c|}{1988} \\
\hline & & & $2 \mathrm{~B}$ & & 3 \\
\hline & & & 0.05 & 0.03 & 0.02 \\
\hline Potamogeton perfoliatus & 0.07 & 0.03 & 0.05 & & 0.04 \\
\hline Potamogeton obtusifolitus & 0.18 & & & 0.04 & \\
\hline Nuphar lutea, leaves & & 0.04 & 0.02 & 0.02 & 0.01 \\
\hline stems & & & 0.02 & 0.01 & 0.01 \\
\hline
\end{tabular}

3.3 Northern pike (Esox lucius)

Mercury concentrations differed between the pikes collected from the unpolluted Lake Kyrösjärvi and the lakes downstream. There was a slight decreasing tendency in $\mathrm{Hg}$ concentrations when moving downstream from the factory. This tendency was similar in the 1970's and 1980's (Figure 4). In the unpolluted lake the correlation coefficient for muscle $\mathrm{Hg}$ and fish weight was lower than in the polluted watercourses.

In the whole material the fish $\mathrm{Hg}$ concentrations (muscle, liver, kidney and gonads) correlated with both fish weight and length. There were no significant differences (except fish size) between males and females. Nor was there any significant difference in the size - Hg correlation between big and small specimens.

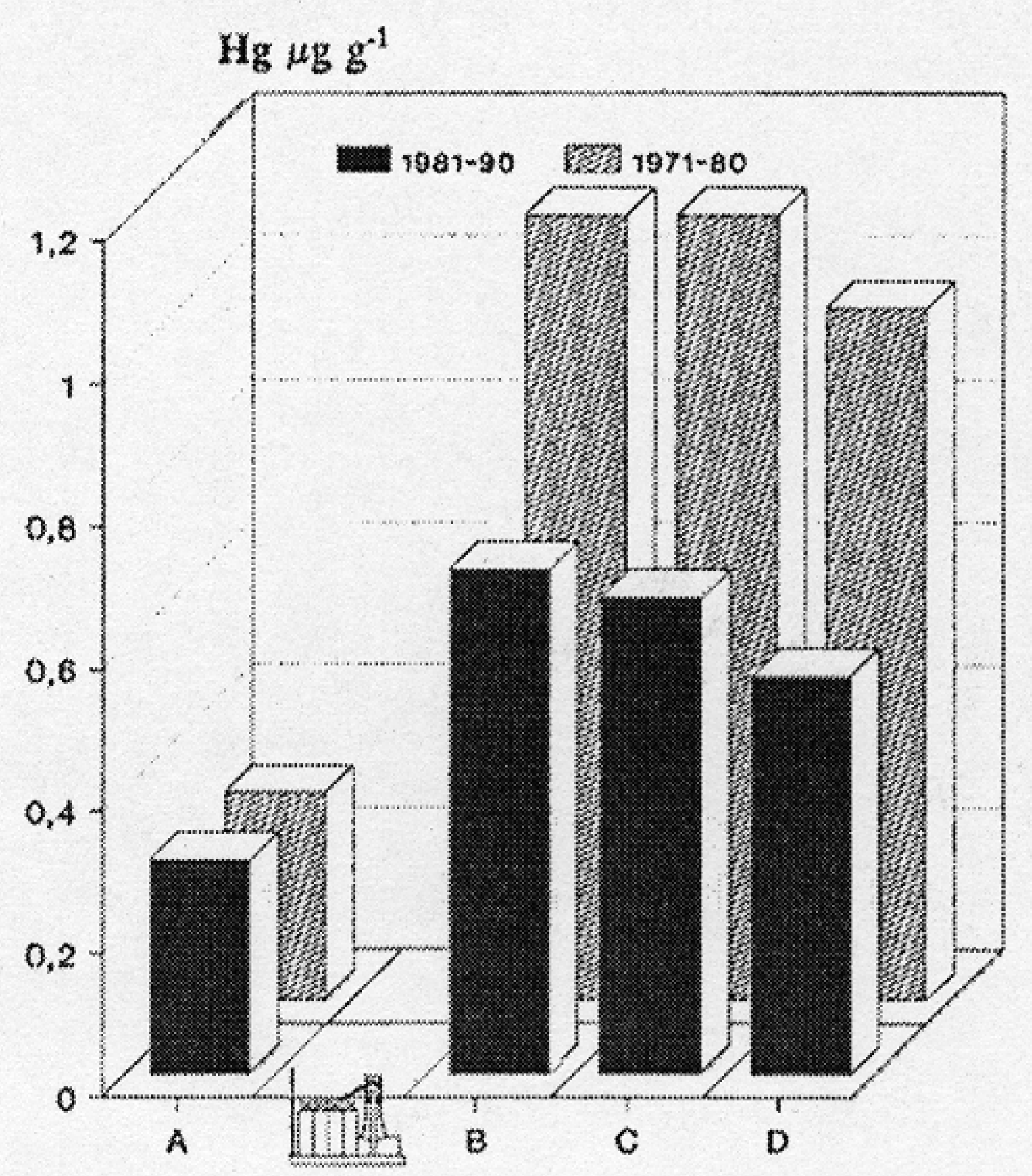

Fig. $5 . \mathrm{Hg}$ concentrations of a $1 \mathrm{~kg}$ pike in the 1970's and in the 1980's in the four subareas. 
The $\mathrm{Hg}$ concentrations in pike normalized for fish size ( 1 or $4 \mathrm{~kg}$ ) decreasid during the 1970's, while the concentrations almost remained unchanged during the 1980’s (Figure 6).

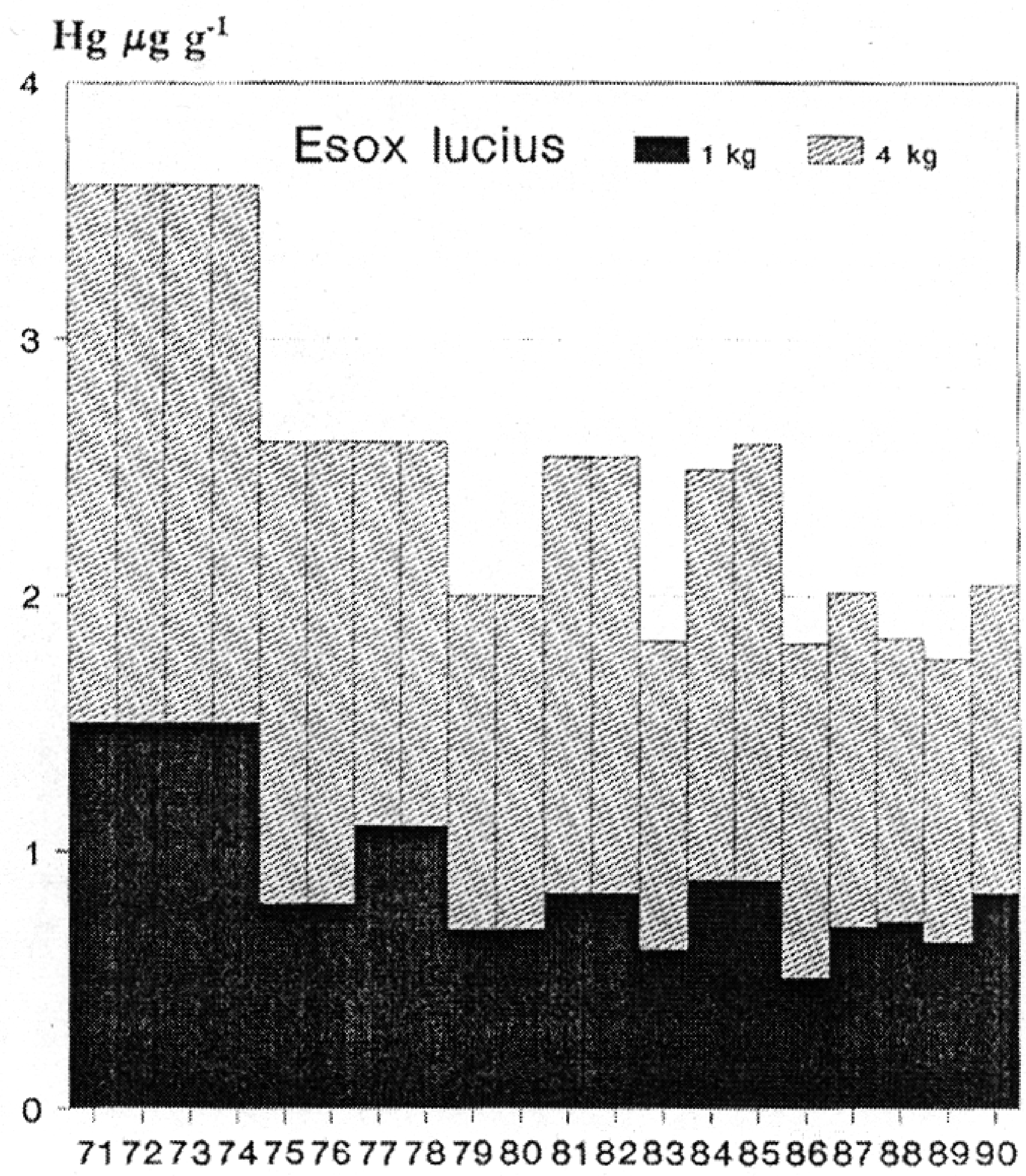

Fig. 6. $\mathrm{Hg}$ concentrations ( $\mu \mathrm{g} \mathrm{g}^{-1} \mathrm{ww}$ ) of pike (1 and $4 \mathrm{~kg}$ ) downstream from the factory (subareas B to D). Mean values were calculated for the 4-yr period 1971-74. the 2-yr periods $1975-76,77-78,79-80$ and $81-82$ and for single years $1983-90$ ).

The $\mathrm{Hg}$ concentrations in pike usually decreased in the order: muscle > liver $=$ kidney $>>$ gonads (Figure 7). 
Fig. 7. $\mathrm{Hg}$ concentrations ( $\mu \mathrm{g} \mathrm{g}^{-1} \mathrm{ww}$ ) of pike muscle, liver, kidney and gonads in relation to the fish weight.

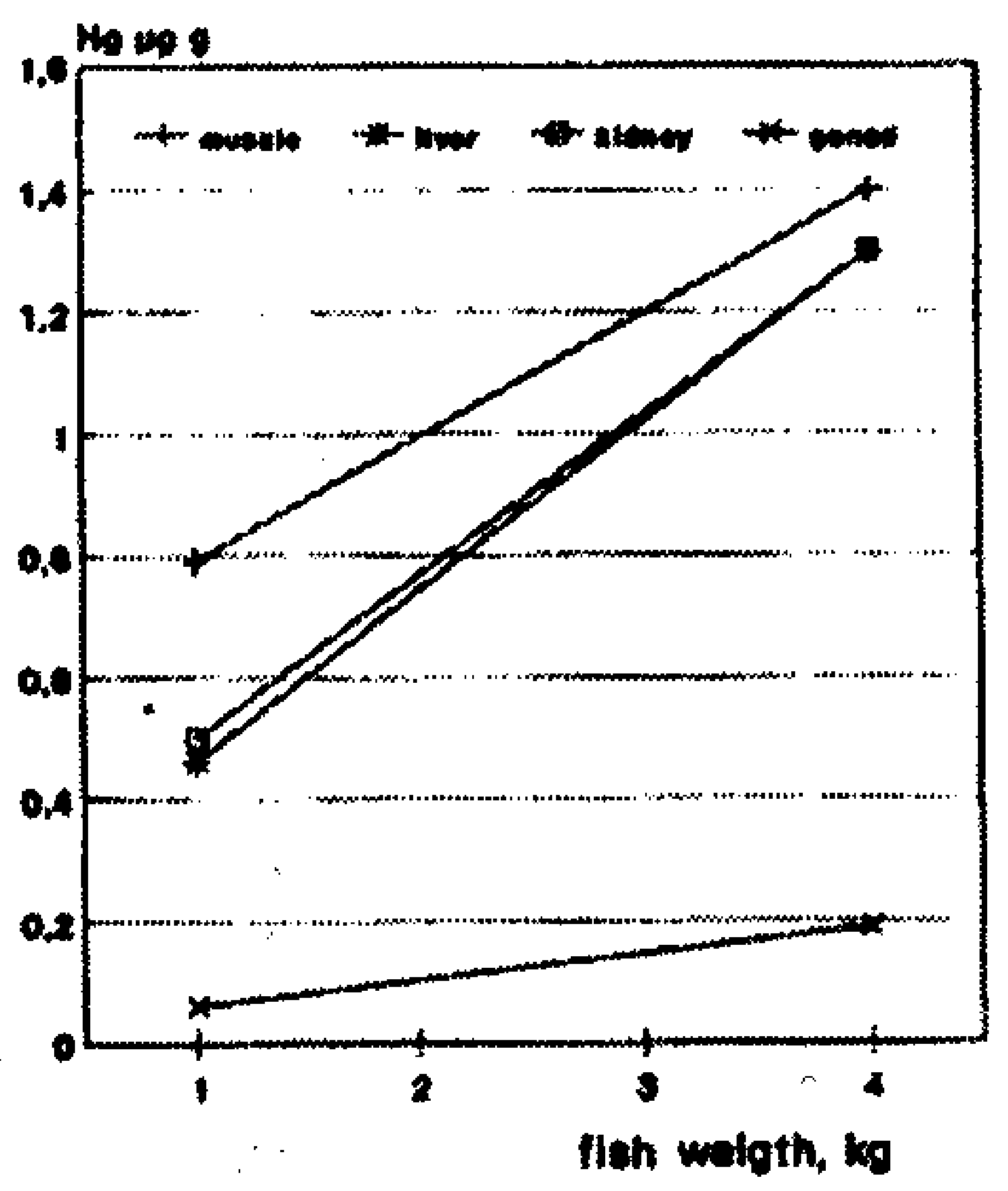

Table II. Correlation matrix for some parameters studied.

fish weight fish length muscle $\mathrm{Hg}$ liver $\mathrm{Hg}$ kidney $\mathrm{Hg}$

fish length

$\mathrm{N}$

muscle $\mathrm{Hg}$

$\mathrm{N}$

muscle $\mathrm{Hg}$ oo

$\mathrm{N}$

muscle $\mathrm{Hg} \odot 8$

$\mathrm{N}$

liver $\mathrm{Hg}$

$\mathrm{N}$

kidney $\mathrm{Hg}$
$\mathrm{N}$

gonad $\mathrm{Hg}$

$\mathrm{N}$
$0.929^{* *}$
234

$\begin{array}{ll}0.666^{* *} & 0.686^{* *} \\ 294 & 234\end{array}$

$0.520^{\circ}$

21

$0.538^{*}$

21

$\begin{array}{ll}0.806 \cdots & 0.796 \cdots \\ 76 & 76\end{array}$

$0.750^{\circ * *}$

$0.758^{* * *}$

129

$0.913^{* * *}$

129

129

$\begin{array}{ll}0.686^{* * *} & 0.687^{* *} \\ 123 & 123\end{array}$

$0.771^{\circ \cdots}$

123

$0.736^{* *}$

123

$\begin{array}{lllll}0.612^{* *} & 0.644^{\cdots *} & 0.762^{\cdots *} & 0.669^{\cdots \cdots} & 0.565^{\cdots *} \\ 72 & 72 & 72 & 72 & 71\end{array}$




\section{DISCUSSION}

The present background concentration of a $1 \mathrm{~kg}$ pike in Finnish lakes other than humic forest lakes has been estimated to $0.44 \mu \mathrm{g} \mathrm{g}^{-1}$, which is significantly higher than the estimated preindustrial background value 0.18 to $0.33 \mu \mathrm{g} \mathrm{g}^{-1}$ (Verta et al., 1986; Verta, 1990).

The Hg level in fish in Hämeenkyrö still exceeds the background level. The clear decrease in the 1970's has slowed down or stopped. Sediment Hg concentrations are normally analyzed from deep water sedimentation bottoms while less attention is paid the littoral zone. No $\mathrm{Hg}$ should be released from the deep water sediment in Lake Kirkkojärvi. The littoral sediments are in more intensive contact with mixing forces in the lake and contain, at least in some parts of the lake, more $\mathrm{Hg}$. These sediments may consequently be a factor contributing to the elevated $\mathrm{Hg}$ level in the watercourses downstream the factory.

Humic substances occurring in water and sediments may increase the release of $\mathrm{Hg}$ from the sediments in these polyhumic lakes (Miller, 1975). The Hämeenkyrö watercourse is rather eutrophic with a dense fish population. Intensive fishing may be one method to reduce the $\mathrm{Hg}$ level in the aquatic ecosystem.

From the development of $\mathrm{Hg}$ concentrations in pike it is impossible to make any exact predictions concerning the future development of the concentrations. It is however evident that no essential decrease in the $\mathrm{Hg}$ level will occur in the near future. A periodic monitoring of the situation is needed.

\section{Acknowledgments}

I am indebted to Mr. Pekka Kuukka and other fishermen in Hämeenkyrö for providing fish samples and to the Kokemäki River Water Protection Association for unpublished results.

\section{REFERENCES}

Anon: 1976, 'Kyröskosken alapuolisen vesistön vahinkoarviota täydentävä kalatalousselvitys'.- Vesitekniikka Oy, Helsinki, Rep. 1851, 84 p.

Lodenius, M.: 1980, Ann Bot Fennici 17,336.

Lodenius, M,: 1988, Suomen Kalatalous 53:14.

Mankki, J.: 1982, Kokemäenjoen vesistön vesiensuojeluyhdistys Julk 139:1.

Mankki, J.: 1989, Kokemäenjoen vesistön vesiensuojeluyhdistys, Julk 215,10.

Mankki, J. and Näsi, S.: 1985, Kokemäenjoen vesistön vesiensuojeluyhdistys, Julk 166,1 .

Miller, R. W.: 1975, Verh Internat Verein Limnol 19,2082.

Nuorteva, P., Häsänen, E. and Nuorteva, S.-L.: 1975, Ympäristö ja Terveys 6,011. Nuorteva, P., Lodenius, M. and Nuorteva, S.-L.: 1979, Aquilo Ser Zool 199,97. Suominen, J., Häsänen, E. and Nuorteva, P.: 1977, Luonnon Tutkija 81,122. 
Verta, M.: 1990, Publ Water Environ Res Inst, Nat Bd Waters, Finland 6,5.

Verta, M., Rekolainen, S., Mannio, J. and Surma-Aho, K.: 1986, Publ Water Res Inst, Nat Bd Waters, Finland 65,21. 